\title{
Meeting the needs of children in islamic boarding school with monitoring child growth
}

\author{
F.E. Naufalina \& M. Hisyam \\ Telkom University, Bandung, Indonesia
}

A. Ahmad

Universitas Bunda Mulia, Jakarta, Indonesia

\begin{abstract}
The parenting of children by their parents is very instrumental in forming the basis of children's education and development. The connection between children, parents, and the boarding school system is also very important in the process of continuing that education. Parental concerns for children have become very common, especially for children who have just graduated from elementary school. The purpose of parenting is to build bonds between children and their parents and guide children to be able to adapt well to their social environment. With everyone so connected to their gadgets to meet their daily needs these days, a digital application is necesawry solution to overcome these concerns is monitoring children with the content of an application for their parents.
\end{abstract}

Keywords: Islamic Boarding School, Children Growth, Parenting, Application, Graphic Design

\section{INTRODUCTION}

Education plays a critical role in helping to raise children to be quality people who are able to socialize well with their environment. The way parents educate and care for their children is a form of education. Good development and growth of a child are determined by the way parents to raise, care, pay attention, and educate them as they grow up. The boarding school environment must therefore be formed at least in the same way as the family environment so that it can contribute to developing the character of children.

The study of parenting from an Islamic or psychological perspective has been widely discussed, resulting in a variety of parenting styles that do not have targets on how to create children who can become a quality generation. Many studies on how to parent children still do not take into account the current time or religious teachings. The character of a child and his/her concept of self is a reflection on the parenting they received by their parents (Fawaid \& Hasanah 2020).

Boarding schools are primarily designed with the vision and mission to educate students, help them develop good morals, and guide them to use their abilities to best serve the community. Boarding school modernization aims to perfect the Islamic boarding school educational system and also establish boarding schools as centers for community development (Hasbullah 1999). Boarding school is an option for parents who are not able to oversee their children's education at home due to lack of time or knowledge.

In previous research (Azizah 2013), many parents sometimes mistakenly interpret the role of Islamic boarding schools as a system that totally takes over the entire education of children, however, students still need the support of their parents back home. Added by Katz (1997), children who get receive and assistance from their parents are able to learn and progress better than children who do not receive it. Many studies have shown that parental support offers infinite benefits to their children. 
In psychological research (Devi \& Pihasniwati 2017), the adjustment of children in Islamic boarding schools is closely related to the communication that exists between parents and children. Therefore, the better the communication between parents and children, the better the level of selfadjustment, and conversely, the worse the communication between parents and children, the lower the level of self-adjustment in the boarding school. Due to the boarding school system which requires students to live in dormitories, the number of meetings between parents and children is reduced, therefore according to Fatimah (2008) higher quality interaction between them is more important that quantity as quality communication can build a sense of closeness between parents and children.

In other psychological research, Monica (2017) reports that the closeness of parents to children also plays a significant role in a child's self-confidence while away at Islamic boarding school. The closer the parents are to the children, the higher the level of self-confidence in a child. In addition, according to Nurjanah \& Heryadi (2020), parental closeness also has a significant effect on children's social intelligence. At the Modern Miftahunnajah Islamic Boarding School, the effective contribution of parent-child closeness contributed $12.1 \%$ to children's social intelligence. It can be concluded that the closeness of parents to children also has a significant effect on the development process of children in Islamic boarding schools.

The purpose of this study is to help parents monitor development and meet the needs of their children while they are away at boarding schools. Parental support usually includes moral support for psychological fulfilment which includes affection, modeling, guidance and direction, encouragement, enthusiasm, motivation, and confidence, where the attention of parents is the hope of all children in their growth and development. With the development of technology, one solution to help parents monitor their children is the creation of a digital application.

\section{METHOD}

The method used in this research is a qualitative approach by collecting data through literature study, interviews, observations, and questionnaires. After data collection, the next method is to analyze data using SWOT for application content design requirements.

\subsection{Method of collecting data}

Through the literature study method, data collection is done by looking for references on how parents care for children so that there is a correlation with the needs of the main subject on this research topic and the perspective and context. The interview is a conversation that aims to explore thoughts, concepts, personal experiences, convictions, and views of sources, or to obtain information from sources about events that cannot be observed directly by the researcher or about events that occurred in the past (Soewardikoen 2013). Interviews conducted are direct and indirect. In addition, this method will be carried out together with the observation method. Observations were made at the Daar El-Qolam Islamic Boarding School. The resource persons to be interviewed were the boarding school and the parents. The questionnaire is a way to obtain data in a relatively short time because at the same time many people can be asked to fill in the written answer choices provided (Soewardikoen 2013). The questionnaire was made as secondary data and distributed to the parents. The results obtained from the SWOT analysis will be designed to suit the needs of children in boarding schools and their parents.

\section{RESULT AND DISCUSSION}

\subsection{Segmentation, targeting, and positioning}

The customer segmentation of this application is parents aged 30-50 years, both male and female. Social status is emphasized more for middle- to medium- and upper-middle class in big cities in 
Indonesia. The target users are parents who use smartphones to meet their daily needs, with a medium lifestyle that prioritizes practicality in carrying out daily activities. As a parent who wants to monitor the development and meet the needs of their children easily, efficiently, and practically, application content will be created that can be used to monitor developments and meet the needs of children in the Daar El-Qolam Islamic Boarding School.

In this application, parents receive various kinds of information about health, education, finance, and children's activities in Islamic boarding schools. However, parents can also purchase items for their children's needs through the app as well as communicate through social media features provided in the application with the school, as a means to convey messages to their children. This application is designed to be modern and dynamic, targeted at the middle- to upper-middle class.

\subsection{SWOT analysis}

From the SWOT analysis, we obtained the desire of boarding schools, as well as the government, to develop application design content for parents designed to suit the needs of their children in boarding schools.

Table 1. SWOT analysis from the interview and observation method.

\begin{tabular}{|c|c|c|}
\hline & Strength & Weakness \\
\hline & $\begin{array}{l}\text { Accredited Education (A) } \\
\text { Have an international program } \\
\text { The slogan "Caring for tradition } \\
\text { and responding to moderniza- } \\
\text { tion" }\end{array}$ & $\begin{array}{l}\text { Do not have an application that } \\
\text { can be used by parents to monitor } \\
\text { children's development }\end{array}$ \\
\hline $\begin{array}{l}\text { Opportunity } \\
\text { The phenomenon of tech- } \\
\text { nological development } 4.0 \\
\text { as well as government sup- } \\
\text { port for the development of } \\
\text { Islamic boarding schools }\end{array}$ & $\begin{array}{l}\text { With the development of tech- } \\
\text { nology } 4.0 \text { and support from } \\
\text { the government for the develop- } \\
\text { ment of Islamic boarding schools, } \\
\text { Daar El-Qolam Islamic Boarding } \\
\text { Schools better can realize their } \\
\text { slogans }\end{array}$ & $\begin{array}{l}\text { The design of this application } \\
\text { could be one step for the Daa El- } \\
\text { Qolam Islamic Boarding School } \\
\text { in responding to the development } \\
\text { of technology } 4.0\end{array}$ \\
\hline $\begin{array}{l}\text { Threat } \\
\text { Some Islamic boarding } \\
\text { schools have implemented } \\
\text { applications for parents }\end{array}$ & $\begin{array}{l}\text { Accreditation (A) and interna- } \\
\text { tional programs can be one aspect } \\
\text { of excellence in competing with } \\
\text { other Islamic boarding schools } \\
\text { that have applied applications for } \\
\text { parents }\end{array}$ & $\begin{array}{l}\text { A good application design in } \\
\text { accordance with user needs will } \\
\text { make this application more func- } \\
\text { tional for all needs }\end{array}$ \\
\hline
\end{tabular}

\subsection{Message and communication concept}

Based on the data obtained through interviews, questionnaires, and observations that were made to answer the background of parents' concerns about the needs of children in Islamic boarding schools, the concept of this application was born. The concept of the message to be conveyed is the trust of parents about child parenting in Islamic boarding schools. This is one of the important factors that can influence the success of children in boarding school. With this platform, it is expected that parents can increase trust in children and Islamic boarding schools, especially Daar El-Qolam.

The concept of communication that will be made in this design is an application related to the User Interface and User Experience which is one of the fields of Graphic Design. Mobile apps are used as the output of this design because they are in accordance with the target, specifically parents who prioritize ease in their daily activities. To achieve the engagement of design functions and user 
needs, in this study the AISAS (Attention, Interest, Search, Action, Share) approach is used as a conceptual strategy to attract the user's attention to find out more about this application. Besides that, boarding schools will also place ad banners to advertise their boarding school environment.


Figure 1. Strategy to attract the user's attention: (1) stand banner, (2) poster (both placed at boarding school) and (3) billboard and (4) poster (both placed in public places).

After the users see large-scale advertisements, they will be able to use this application by downloading it at which point they will see promotional media, such as social media, brochures, and x-banners, are placed there by their school. Users can download this application on the Google Playstore or Apple Store, followed by downloading and using this application as a medium to monitor their children's development so as to meet their needs.

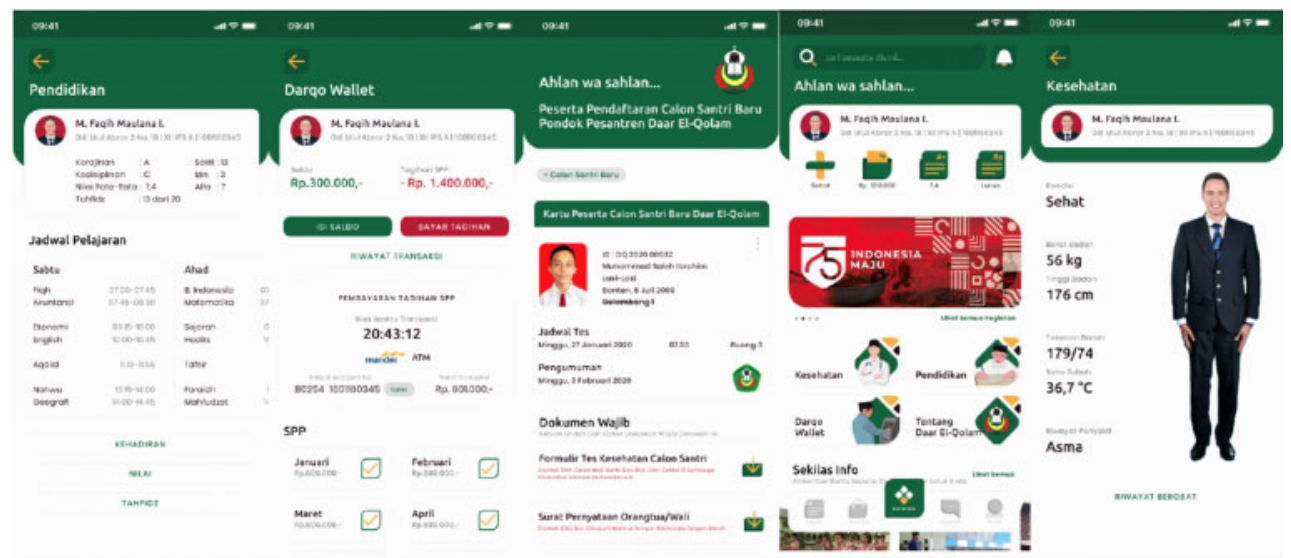

Figure 2. Example of the mobile application, showing strategy for encouraging users to utilize the application. 
Furthermore, after users use the design content contained in this application, they will share their experiences on social media sites such as Instagram, WhatsApp, Line, Facebook, and others.

\section{CONCLUSIONS}

Parents' concerns about wrong parenting, as well as the perception that children who attend a boarding school will be good children, can be seen as a solution to keep monitoring child development from both the point of view of the school and of parents. By utilizing UI/UX technology, it becomes possible for a parent to meet their child's needs while away from home.

The design of this application was carried out during the COVID-19 outbreak, which certainly made obtaining maximum data impossible. However, the design content that exists in the current design can be developed not only for boarding schools, but also for playgroups or daycare.

\section{ACKNOWLEDGMENTS}

The author would like to thank Mr. KH. Ody Roshihuddin, Chairman of the Islamic Boarding School Daar El-Qolam, for allowing us to conduct interviews, as well as the teachers of the school who helped the process by collecting data such as questionnaires and observations in the midst of the current pandemic. It is expected that the outcome of this research will enable parents to mee the needs of their children by monitoring their growth and development.

\section{REFERENCES}

Azizah, Nur. 2013. Dukungan Orangtua Bagi Anak yang Belajar di Pondok Pesantren. Prosiding Seminar Nasional Parenting. STAIN Purwokerto: 133-141.

Devi, Linggarsari, and Pihasniwati. 2017. Hubungan antara Komunikasi antara Orang Tua-Anak dengan Penyesuaian Diri Santri di Pondok Pesantren Tradisional dan Modern. UIN Sunan Kalijaga Yogyakarta.

Fatimah, E. 2008. Psikologi Perkembangan: Perkembangan Peserta Didik. Bandung. Pustaka Setia.

Fawaid, Achmad and Hasanah Uswatun. 2020. Pesantren dan Religious Authoritative Parenting: Studi Kasus Sistem Wali Asuh di Pondok Pesantren Nurul Jadid. Ilmu Ushuluddin 19(1):27-40.

Hasbullah, Drs. 1999. Sejarah Pendidikan Islam di Indonesia: Lintasan Sejarah Pertumbuhan dan Perkembangan. Jakarta: PT Raja Grafindo Persada.

Katz, Adrienne. 1997. Membimbing Anak Belajar Membaca. Alih Bahasa: Liliana Wijaya. Arcan: Jakarta.

Monica, Anggita Eva. 2017. Hubungan Kelekatan Orangtua-Anak dengan Keperecayaan Diri Santri Pondok Pesantren di Surakarta. Universitas Surakarta.

Nurjanah and Heryadi, Adi. 2020. Jurnal Psikogenesis: Kelekatan Orang Tua dan Kecerdasan Sosial pada Remaja di Pondok Pesantren Modern. STIPSI Yogyakarta.

Soewardikoen, D. W. 2013. Metodologi Penelitian Visual. Bandung: Dinamika Komunikasi. 




Taylor \& Francis Taylor \& Francis Group

http://taylorandfrancis.com 